\title{
Rotten posts and selected fuel: Charcoal analysis of the first Middle Neolithic village identified in Provence (Cazan-Le Clos du Moulin, Vernègues, Bouches-du-Rhône, South of France)
}

\author{
Claire Delhon ${ }^{\mathrm{a},{ }^{*}}$, Clément Moreau ${ }^{\mathrm{b}}$, Frédéric Magnin ${ }^{\mathrm{c}}$, Luke Howarth ${ }^{\mathrm{d}}$ \\ a CEPAM, UMR 7264, CNRS, Université Côte d'Azur, Nice, France \\ ${ }^{\mathrm{b}}$ Archeodunum, 500 Rue Juliette Récamier, 69970, Chaponnay, France \\ ' IMBE, Aix-Marseille Université, CNRS, IRD, Avignon Université, Europôle Méditerranéen de l'Arbois, BP 80, F-13545, Aix-en-Provence, Cedex 4, France \\ ${ }^{\mathrm{d}}$ Archéologie des sociétés Méditerranéennes, UMR 5140, CNRS, 390 Avenue de Pérols, 34970, Lattes, France
}

\begin{abstract}
A B S T R A C T
"Cazan-Le clos du Moulin" is an open-air Middle Neolithic site located in the South of France near the village of Vernègues. The excavation of this site has, for the first time in the area, allowed us to reconstruct up to a dozen domestic buildings from the late Chassey culture (4100-3800 BCE), arranged around an area occupied by heated stone combustion structures. Because of the partial erosion of the archaeological horizons, artefacts and ecofacts related to the Neolithic occupation were only found in the fills of structures. Charcoal analysis was carried out on samples from the postholes, the heated-stone hearths and a well.

The anthracological results show a selection of natural resources depending on the use of the wood: timber or fuel. The size required for the posts can restrict the scope of the species suitable for timber: oak seems to be preferred for that purpose. On the contrary, the choice of fuel wood seems to be less constrained by technical limitations. Nevertheless, one particular species, Arbutus unedo, accounts for the bulk of the wood gathered for fuel supply, however it was certainly not the only woody resource available during the Middle Neolithic. Overall, charcoal analysis at Cazan-Le Clos du Moulin shows that wood harvesting - as recorded in the fills of structures - is selective. This selection could be imposed by purely technical requirements that we can only partly perceive or by cultural necessity which remains beyond our understanding, but, beyond this, the choices are probably guided by land and vegetation resource management in order to permit the coexistence of various wood-consuming activities in a single territory and to favor the exploitation of easily accessible fuel.
\end{abstract}

\section{Introduction}

The Middle Neolithic in southern France is identified as the period when the impact of agro-pastoral activities on the Mediterranean forest begins being recorded in charcoal assemblages, in the form of an increase of species from evergreen formations (evergreen Quercus, Buxus sempervirens, Phillyrea sp./Rhamnus alaternus...) to the detriment of the mixed deciduous oak forests species (Heinz and Thiébault, 1998; Brochier et al., 1998; Thiébault, 1997, 2001; Battentier et al., 2015). This pattern is based on data

\footnotetext{
* Corresponding author.

E-mail addresses: claire.delhon@cepam.cnrs.fr (C. Delhon), c.moreau@ archeodunum.fr (C. Moreau), lukehwth@gmail.com (L. Howarth).
}

from stratified sites where the sampling of dispersed charcoal was possible, i.e. caves or shelters often used for pastoral activities. Hence, it mainly reflects the vegetation changes and the management of wood in the karstic areas, which represent only a part of the socio-economic practices and territory. In the middle Rhône valley, charcoal recovered from "natural" deposits (i.e. outside archaeological horizons) and from archaeological structures, together with other data (phytolith, molluscs, pedology) provide a different image which has allowed us to propose the hypothesis of a multi-purpose management of the resources resulting in the "domestication" of the woodland (Delhon et al., 2009). Recently, several Middle Neolithic open-air sites have been excavated in Provence (South of France), among which Cazan-Le Clos du Moulin which provides, for the first time, clear evidence of persistent 
structured habitat. These recent advances in the understanding of the organization of middle Neolithic dwellings sheds new light on the everyday life of these populations, including wood gathering, for fuel or timber, which is one of the most persistent activities.

\section{Cazan-le clos du moulin in its regional setting}

"Cazan-le Clos du Moulin" is an open-air Middle Neolithic site located in the South of France, $60 \mathrm{~km}$ north-west from Marseille and the Mediterranean Sea, in the village of Vernègues (Fig. 1). The excavation by Archeodunum ${ }^{\odot}$ in 2013 brought to light numerous postholes which, for the first time in the area, allows us to reconstruct several domestic buildings from the middle Neolithic (late Chassey culture, 4100-3800 BCE), arranged around an area occupied by heated stone combustion features (Moreau et al., 2014) (Fig. 2).

The site is located within a small valley $(1 \times 5 \mathrm{~km}$, at 170 asl, aligned NE-SW) which forms part of the drainage basin of the river Durance. A few hundred meters to the north of the site, a series of small water courses join, before flowing northwards to the Durance. The valley forms an interruption between the Massif de Vernègues ( $385 \mathrm{~m}$ ) and the Chaîne des Cotes $(430 \mathrm{~m})$, which is located halfway between the massif of the Petit Luberon $(727 \mathrm{~m})$ and the étang de Berre (coastal lagune). The vegetation is typical of the mesomediterranean belt on calcareous substrata, characterized by sclerophyllous formations with evergreen oak (Quercus ilex and $Q$. coccifera) on stony substrata and mixed forests dominated by deciduous oak (Quercus pubescens) on the deepest soils. Present-day vegetation bears the scars of long-term human's impact: garrigue and sclerophyllous stands cover ancient extensive pastures or burnt areas on skeletal soils formed upon Cretaceous limestones, and Aleppo pine (Pinus halepensis) is well represented throughout on hillsides. Deciduous oak stands are restricted to deep and fresh soils developed upon Oligocene marly limestone, Miocene calcareous sandstone and Quaternary deposits, although Q. pubescens now expands practically everywhere due to a dramatic decrease of sheep grazing. River sides are occupied by stands of poplar (mainly Populus alba) and alder (Alnus glutinosa) mixed with various other riparian species (Ozenda et al., 1970; Molinier et al., 1976). Cultivated plots (and particularly vineyards) cover an important part of the plains extending to the bottom of the hillsides.

The archaeological value of the small valley of Cazan has been known for a long time thanks to archaeological prospection and preceding excavations, but it has been more recently confirmed after several development led excavations. Le Clos du Moulin is located in the core of a $3 \mathrm{~km}$ long area characterized by discontinuous but abundant Middle Neolithic remains (Fig. 1). The site itself proved to be of major importance as it revealed the plans of 10 houses and 3 complex buildings. It was a long anticipated discovery for the Chassey culture, for which dwelling structures were very sparsely documented.

The archaeological material is typical of the local Middle Neolithic (late Chassey culture) and radiocarbon dates range from $5240 \pm 30 \mathrm{BP}(4227-3971 \mathrm{cal} . \mathrm{BC})$ to $5010 \pm 30 \mathrm{BP}(3942-3706 \mathrm{cal}$. $\mathrm{BC}$ ) (Table 1). The very careful excavation in the field and a multidisciplinary analysis of the archaeological data revealed that the site was occupied and abandoned at least three times in probably less than 300 years during the late Chassey culture (Moreau et al., 2015) and that the time span between two occupations was short enough to prevent the total destruction or burying of the previous structures, which were scrupulously avoided for the construction of

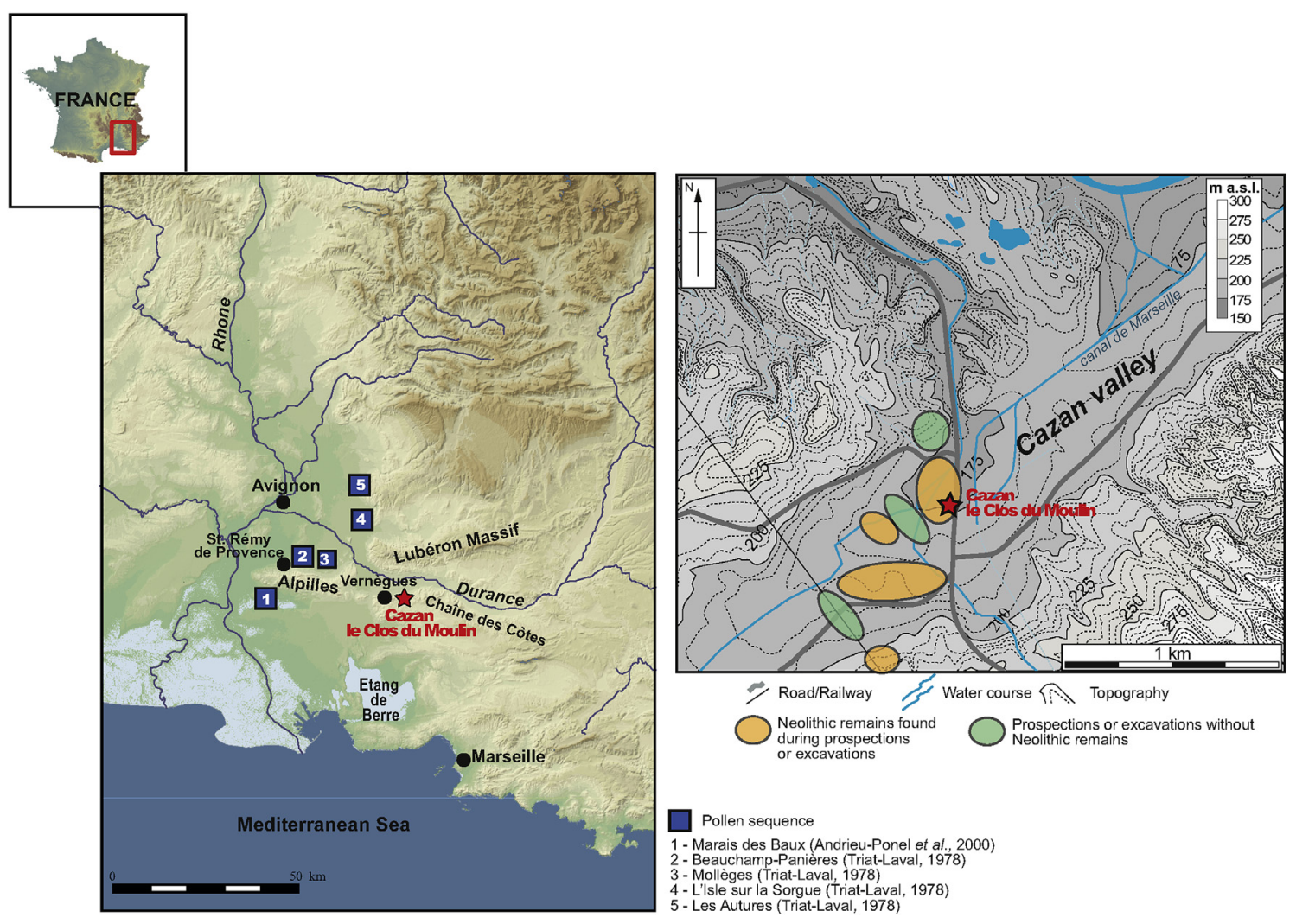

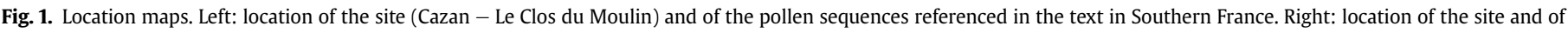
the other principal Neolithic discoveries in the Cazan valley. 


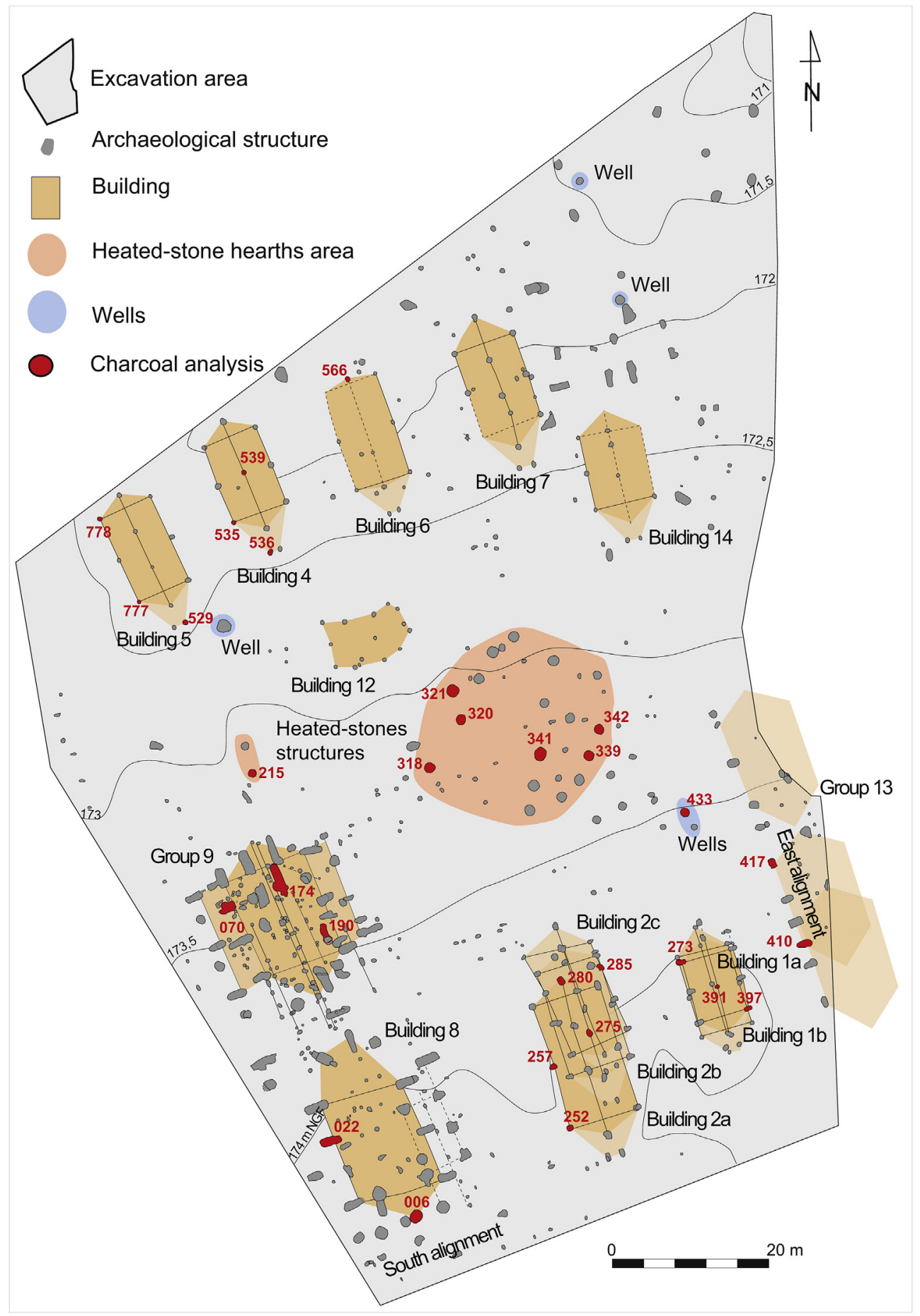

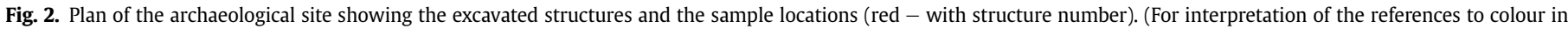
this figure legend, the reader is referred to the web version of this article.)

the new buildings. It is likely that the hearths belong to various occupation phases despite it has not been possible to determine which ones correspond to each phase.

The fills in the postholes are sometimes homogeneous, but several buildings show multiple phases of deposition infilling that could indicate the extraction of the post (buildings 1a, 2a, 2b). Some structures contain reddish clay which could result from wood decomposition (buildings $2 \mathrm{a}, 2 \mathrm{~b}, 4)$ and some have been closed with large blocks (buildings 1a, 2a, 4, 5, 6). All these features tend to suggest the abandonment of the related buildings and thus their precedence over the others. The foundation pits are large structures (up to $2 \mathrm{~m}$ deep) interpreted as holes for big posts. They are rectangular in plan with an unsymmetrically U-shaped profile: there is a soft slope on the external side (which allows an easy insertion of a large piece of timber), while the internal pit wall, against which the post finally stand, is vertical. As the profiles of opposite pits in a same building mirror each other, transversal beams probably connected the posts. 
Table 1

Radiocarbon dates from Cazan-Le Clos du Moulin.

\begin{tabular}{|c|c|c|c|c|c|c|}
\hline ID & Nb. Structure & Stratigraphic unit & Type of structure & Type/Taxa & Results & calibrated date BC (2 sigmas) \\
\hline Beta-387513 & F.433 & 908 & Well & Charcoal/Pinus & $5240 \pm 30 \mathrm{BP}$ & $4230-3970$ \\
\hline Beta-387510 & F.252 & 1650 & Posthole (Building 2a) & Charcoal/Fraxinus & $5200 \pm 30 \mathrm{BP}$ & $4050-3960$ \\
\hline Beta-387508 & F.135 & 594 & Pit (Building 8) & Charcoal/Arbutus & $5110 \pm 30 \mathrm{BP}$ & $3975-3800$ \\
\hline Beta-387514 & F.433 & 916 & Well & Burnt cereal seed & $5100 \pm 30 \mathrm{BP}$ & $3970-3800$ \\
\hline Beta-387509 & F.174 & 1385 & Foundation pit (Building 9) & Charcoal/Arbutus (twig) & $5060 \pm 30 \mathrm{BP}$ & $3950-3790$ \\
\hline Beta-387511 & F.339 & 767 & Heated-stones hearths & Charcoal/Pinus & $5050 \pm 30 \mathrm{BP}$ & $3950-3780$ \\
\hline Beta-387515 & F.536 & 1467 & Posthole (Building 4) & Charcoal/Pinus & $5050 \pm 30 \mathrm{BP}$ & $3950-3780$ \\
\hline Beta-387507 & F.070 & 1423 & Foundation pit (Building 9) & Charcoal/Pop./Salix & $5010 \pm 30 \mathrm{BP}$ & $3940-3700$ \\
\hline
\end{tabular}

\section{Charcoal sampling and identification}

As the archaeological horizons were truncated, the archaeological and bioarchaeological material was only available in the fills of the structures. Charcoal was thus sampled from 15 postholes from 7 houses, 6 foundation pits from 3 buildings, 7 heated-stone hearths and 11 sediment fills of a well. (Figs. 2 and 3). The stratified fill of the well provided two dates: the deepest one is the oldest obtained on the site (4227-3971 cal. BC) and the one at mid-depth is of $5100 \pm 30 \mathrm{BP}(3968-3800 \mathrm{cal}$. BC). Therefore, the charcoal sampled according to the well's stratigraphy potentially constitutes a continuous "long-term" record of the fuel used on the site, contrarily to those from the other structures which are all suspected to be more or less punctual charcoal accumulations.

Admittedly, charcoal "concentrations"- principally in the form of primary deposits such as hearths - are often considered as poor

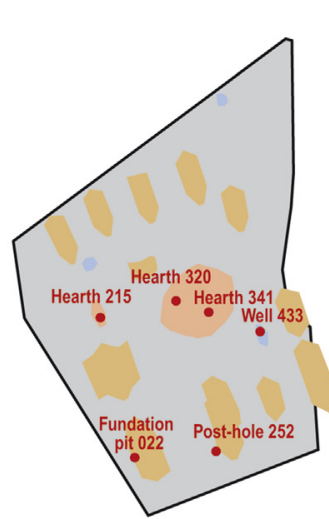

HEARTHS

Type I (small and shallow)
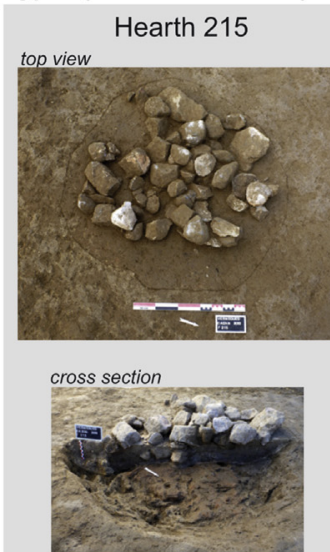

excavated structure

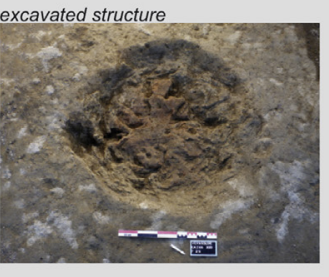

ARCHITECTURAL HOLES

Fundation pit

Pit 022

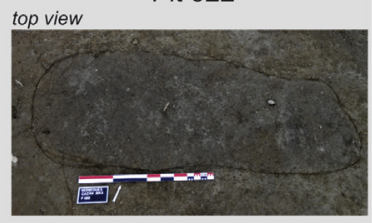

cross section

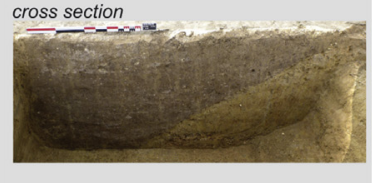

Posthole

Post-hole 252

top view

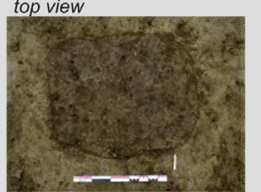

cross section

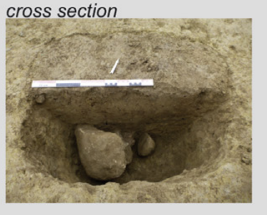

WELL

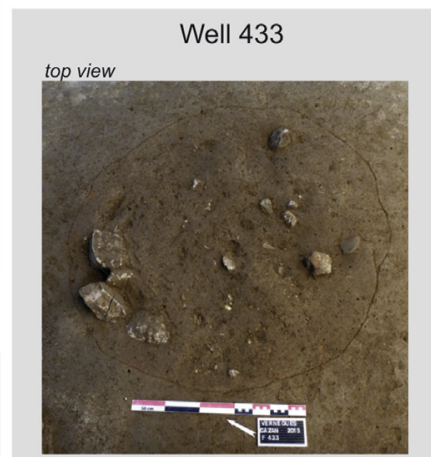

Type II (large and deep)
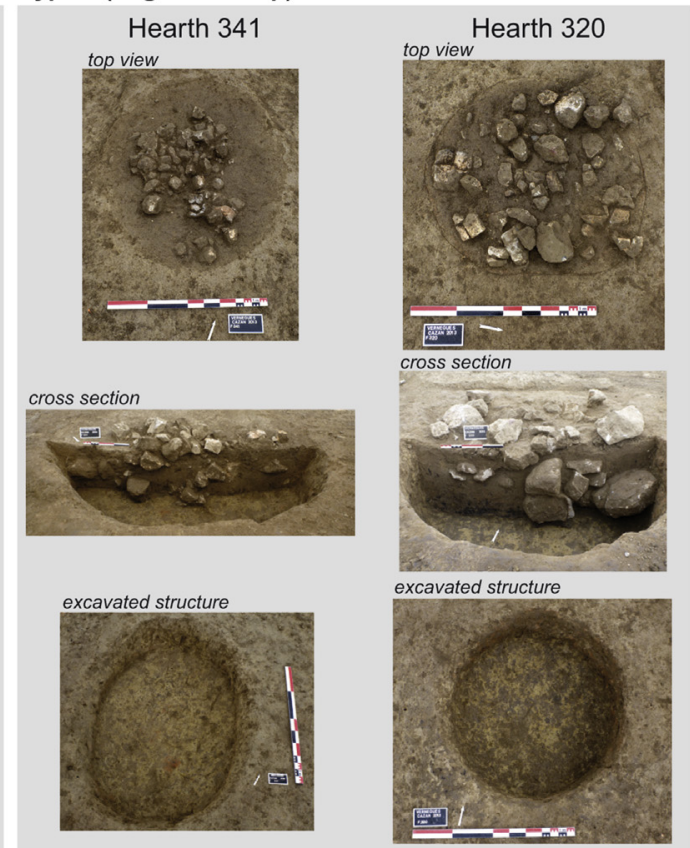

cross section

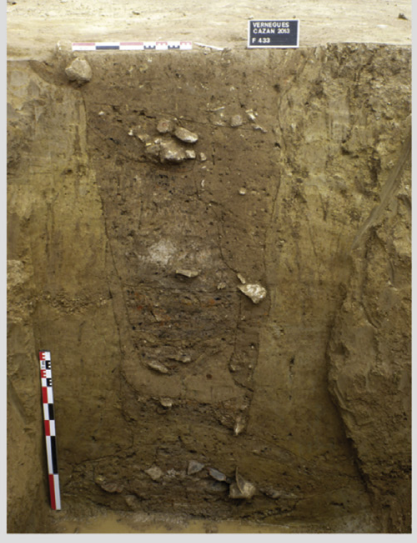

Fig. 3. Examples of structures excavated at Cazan-Le Clos du Moulin. 

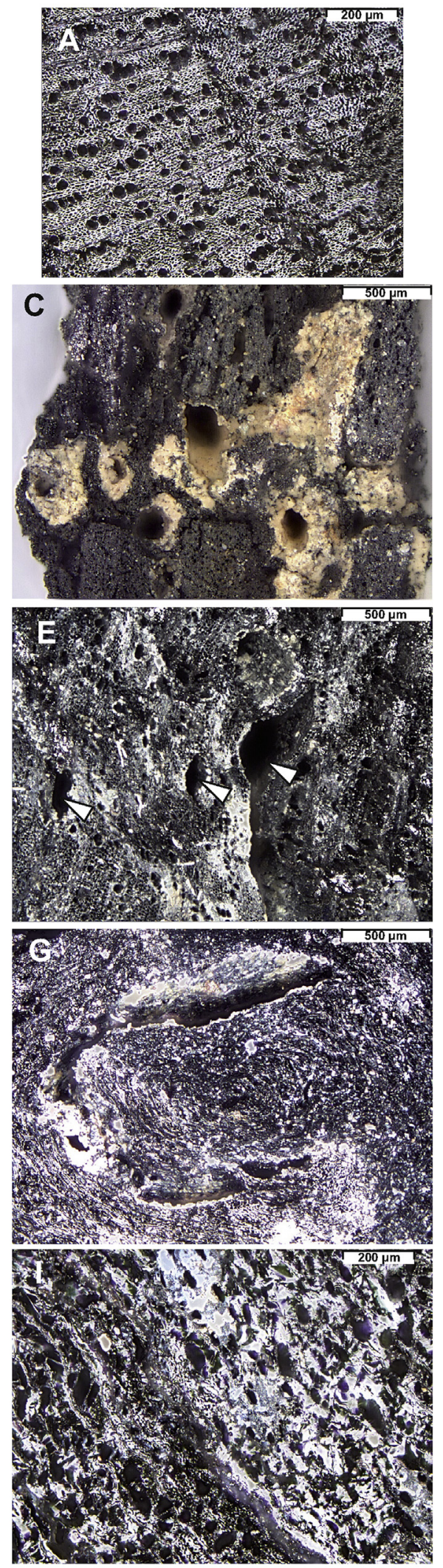
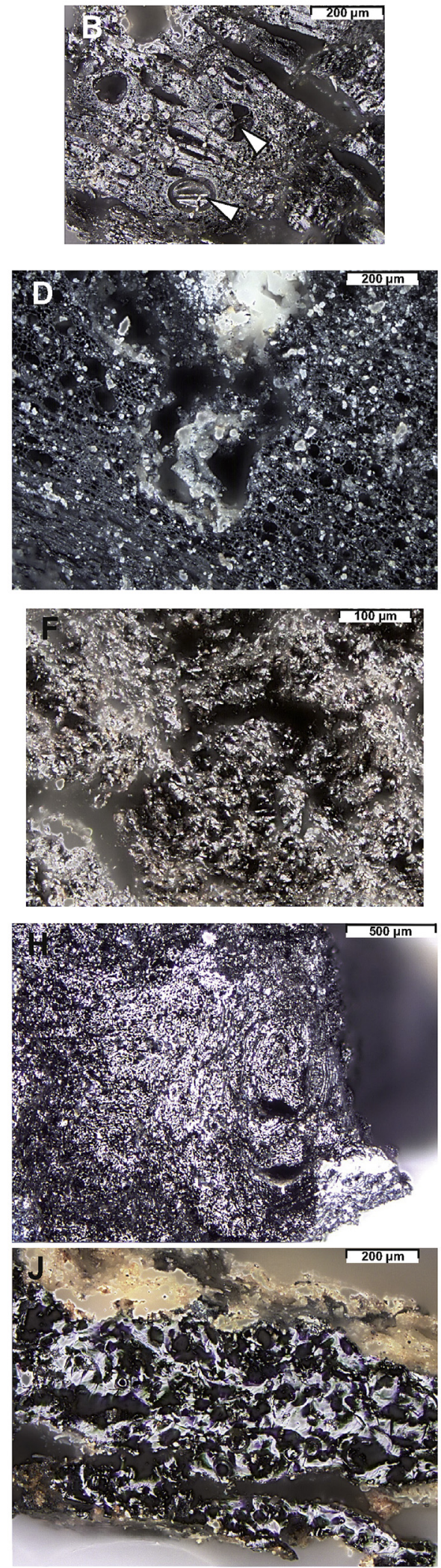

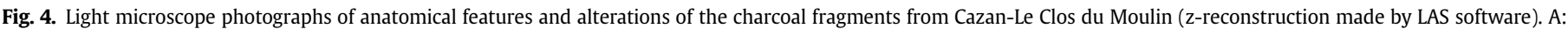

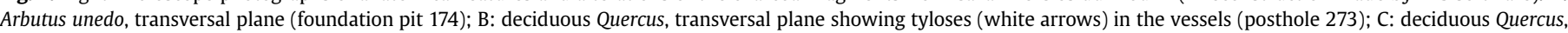

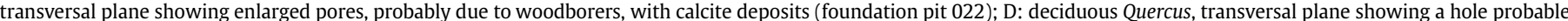

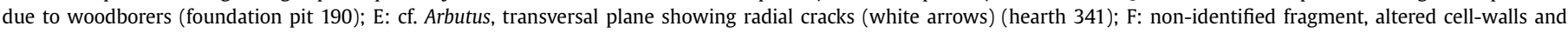

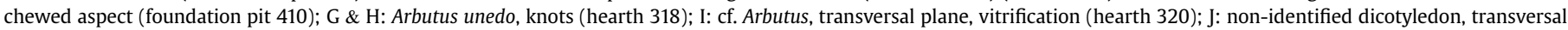
plane, strong vitrification (hearth 321). 
Table 2

Results of the charcoal analysis from Cazan-Le Clos du Moulin.
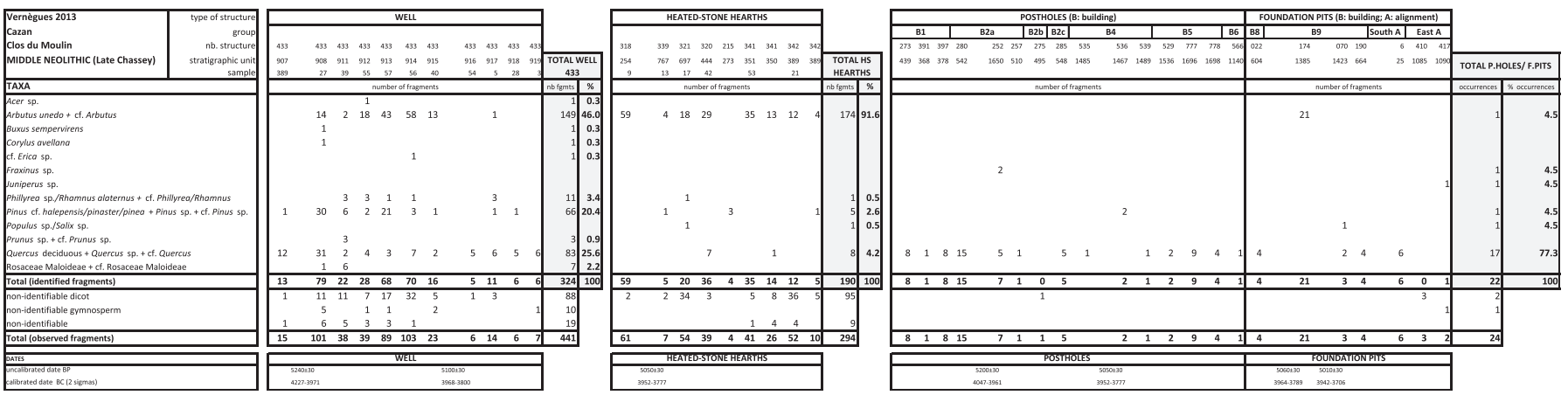

records not only of the vegetation but also of human choices (Smart and Hoffman, 1988; Chabal, 1997; Heinz, 1990; Asouti and Austin, 2005). In such cases, there is a high probability that the abundance of one species corresponds to its last use (or to a single fireevent in cases of stratified deposits) and is not representative of its abundance in the vegetation nor of the usual practices of the inhabitants. Considering that the distortion of the data can however be mitigated by analyzing several "punctual" deposits (Battentier et al., 2016a), 7 hearths were analyzed at Cazan. They are circular and belong to the two different types identified on the field: small ones (diameter $<130 \mathrm{~cm} /$ depth $<30 \mathrm{~cm}$ ), weakly reddened, and larger ones (diameter $>120 \mathrm{~cm} / 30<$ depth $>70 \mathrm{~cm}$ ), more reddened and containing more heated-stone.

Charcoal was recovered in most cases by wet sieving ( 2 and $1 \mathrm{~mm}$ mesh) of the sediment. In some layers where charcoal was very abundant, the sieving stage was skipped and charcoal fragments were directly picked from the raw sediment for the identification. More rarely, a single charcoal fragment was hand-picked in the field. The $2 \mathrm{~mm}$ fraction only was studied (except for sample F433-US 908: $2 \mathrm{~mm}$ and $1 \mathrm{~mm}$ ). Depending on the available number of fragments and on the diversity of each assemblage, the samples were exhaustively or only partly studied. Efforts have been made to identify at least 30 fragments per sample. However, in cases of clearly re-fragmented pieces, of extremely poor preservation of the anatomical features (unidentifiable fragments), or where only a small quantity of fragments was available, this number was not attained.

The anatomical identification of the charcoal fragments was carried out with a reflected light bright field/dark field microscope (X50 to X500). Charcoal fragments were hand-broken in order to allow the observation of the three anatomical sections of wood (transverse, longitudinal-tangential and longitudinal-radial). The observed structures were compared to those described in the atlases of wood anatomy (Schweingruber, 1990; Vernet et al., 2001) and to an extensive reference collection of present-day burnt woods.

Besides the taxonomical information, several other parameters concerning the state of the wood before or after combustion (rotting features, vitrification) were also noted.

\section{Results and interpretations}

Charcoal fragments are sometimes large and abundant, but the preservation of the anatomical features is globally poor. Vitrification, radial cracks, biological degradation such as insect galleries and cell wall collapses - attributed to fungal or bacterial activity (Théry-Parisot, 2001; Théry-Parisot and Texier, 2006) - and anatomical oddities due to the presence of knots are abundant, leading to a low amount of identification (Fig. 4). Knots correspond to the branching of a lateral axis on the trunk or on a bigger branch. At their level, the anatomy is altered and the usual identification criteria (size and abundance of rays, pore size and arrangement) may vary from the standards of the taxon, making the identification problematical. It is not unusual that a single fragment bears several kinds of alteration (knot, vitrification and cracks in particular are often found together), which explains the low rate of identification (23\% of unidentified fragments) and some imprecise determinations (dicotyledon vs gymnosperms). Due to the very similar anatomy of several species, it has not been possible to identify further the Pinus fragments. They all show rather small pinoid (non-fenestriform) cross-fields pits, characteristic of Mediterranean species ( $P$. halepensis, $P$. pinaster, $P$. pinea, excluding P. sylvestris).

The total taxonomic diversity of the site is rather low (Table 2), with only 13 different taxa, among which only 3 are present in several different assemblages (Arbutus unedo, deciduous Quercus and a Mediterranean pine). Phillyrea sp./Rhamnus alaternus is present in few samples from the well and has been observed once in a hearth. All the other taxa appeared in only one or two different samples.

All the taxa refer to mesomediterranean plant formations: the deciduous oak forest (deciduous Quercus, Acer sp., Prunus sp., Maloideae, Corylus avellana pro parte, Buxus sempervirens pro parte, Fraxinus sp. pro parte), evergreen communities (Arbutus unedo, Buxus sempervirens pro parte, cf. Erica sp., Juniperus sp. pro parte, Phillyrea sp./Rhamnus alaternus), pine woods (Pinus sp, Juniperus sp. pro parte) and a riparian formation (Populus sp./Salix sp., Corylus avellana pro parte, Fraxinus sp. pro parte).

\subsection{Postholes and foundation pits (Fig. 5)}

Charcoal from architectural structures (postholes and foundation pits) consists in small assemblages of rather big fragments (from circa 1 to several $\mathrm{cm}$.) and proved to be predominantly monospecific. In the cases where several fragments were available, a single taxon has nearly always been identified (excepted for 1 posthole and 1 foundation pit), and charcoal pieces show anatomical similarities making it probable that they were originally part of the same fragment. In most of the cases, deciduous oak (deciduous Quercus) was identified. In two samples, oak was found together with another taxon: ash (Fraxinus sp.) in the posthole 252 and poplar or willow (Populus sp./Salix sp.) in the foundation pit 70 . Only 3 samples did not provide oak; they proved to be monospecific and consist of pine (Pinus sp.), strawberry tree (Arbutus 


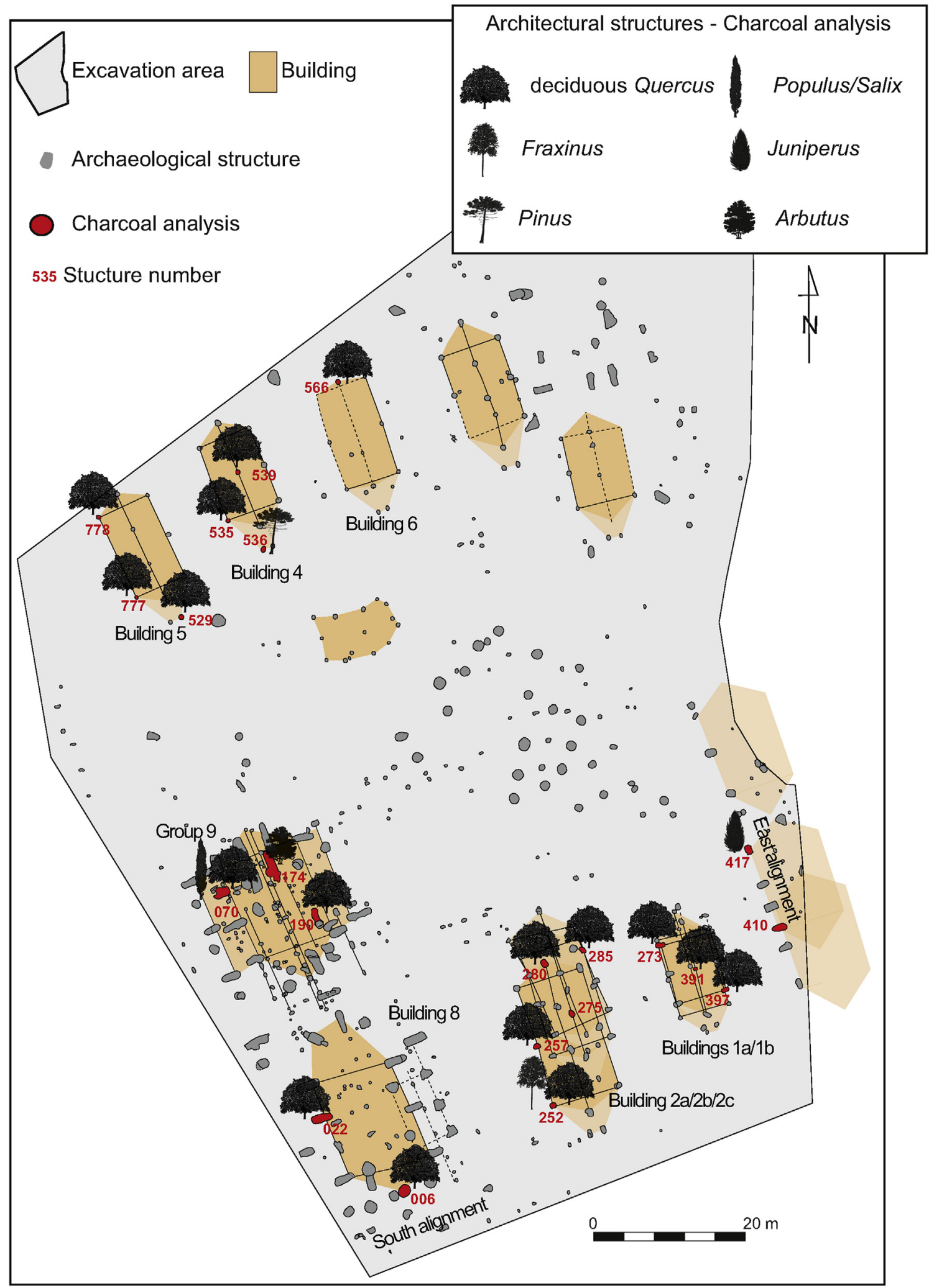

Fig. 5. Results of the identification of the charcoal fragments from the architectural structures (post-holes and foundation pits).

unedo) and juniper (Juniperus sp.). Tyloses are frequent in the vessels of oak charcoal from the architectural features. Although it may be pathological, the formation of tyloses in the vessels is normal and generalized during the ageing process of certain species (Bakour, 2003) and allows the transformation of sapwood into heartwood (duraminization). The heartwood, impregnated with tannins, is much more resistant to biological degradation than functional sapwood which explains it is the only part workable for 
timber. In oak trees, heartwood takes 20 years to appear, but tyloses form as soon as in the second or third growth ring (Ghazil, 2010). If the occurrence of tyloses is not a compelling evidence of old wood, the proportion of vessels clogged with tyloses in deciduous oak increases from the outermost rings (i.e. the youngest ones) to the most internal ones (i.e. the oldest ones) and nearly reaches $100 \%$ in the heartwood (Bakour, 2003). The high abundance of tyloses suggests that charcoal is from heartwood, either because that part was chosen per se or just because it is always present in large diameter pieces of oak. Oak heartwood offers the best durability among all the woody resources in Europe (Centre Technique du Bois et de l'Ameublement, 1992; Association des ingénieurs de l'école supérieure du bois, 2013), making it the most suitable building material, but also the part the less subject to decay if it is used without distinction with sapwood.

Because the assemblages are mainly constituted by one single species, because this species is the same in most of the cases (deciduous oak), and because the remains evoke the material (deciduous oak heartwood) the most suitable for timber (Centre Technique du Bois et de l'Ameublement, 1992; Association des ingénieurs de l'école supérieure du bois, 2013), it is likely that the charcoal fragments are the remains of the posts themselves rather than intrusive particles. Hence, in order to propose a quantification of the relative abundancy of the taxa in the charcoal assemblages from these structures, we chose to consider all the fragments from a same taxon found in a same pit as a single original fragment. The total proportions (percentages) of the taxa among the architectural features are then calculated on the basis of the occurrences (Delhon, 2016). It must be noted that the sum of the occurrences is low (22), thus the relative proportions are just a point of information and must be cautiously used.

Oak represents around $77 \%$ of the occurrences (Table 2) and is present in more than $84 \%$ of the pits ( 17 over the 20 pits which provided identifiable charcoal) in which determinable charcoal was found. Thus, the Neolithic people from Cazan would have chosen oak among the available trees for the construction of their buildings during the successive occupations.

Despite the great durability of oak heartwood, rotting features are very abundant, in the form of insects' galleries and cell walls collapses attributed to fungal or bacterial attacks (Théry-Parisot, 2001), suggesting that the posts may have begun to decay before being charred.

\subsection{Heated-stone hearths}

The hearths provided large quantities of large fragments but the amount of identifiable charcoal is lower than expected (less than $65 \%)$. The spectra is quite different from that of the postholes (Table 2 and Fig. 6A and B): oak is only present in two samples and represents only $4 \%$ of the fragments, while Arbutus is present in all the samples except for one (which only gave 3 fragments of pine). It nearly accounts for $92 \%$ of the identifications. Mediterranean pine was present in 3 different assemblages, the other taxa (Phillyrea sp./ Rhamnus alaternus and Populus sp./Salix sp.) appeared only once each.

The important amount of non-identified fragments is in part due to the advanced stage of vitrification of most of them and to the abundance of knots whose anatomy is often too atypical to allow a reliable identification. However, the few preserved anatomical features (in particular typical spiral thickenings) were often compatible with that of Arbutus. This could indicate that this tree, although already dominating the assemblages, is underestimated in our results. Notwithstanding this, a potential taphonomical bias in favor of Arbutus should also be taken into account. Knots and vitrification are frequent on Arbutus fragments. If vitrification makes charcoal less crumbly and if the absence of orientation of the wood grain makes knots less sensitive to fragmentation, differential preservation could have affected the charcoal record, to the benefit

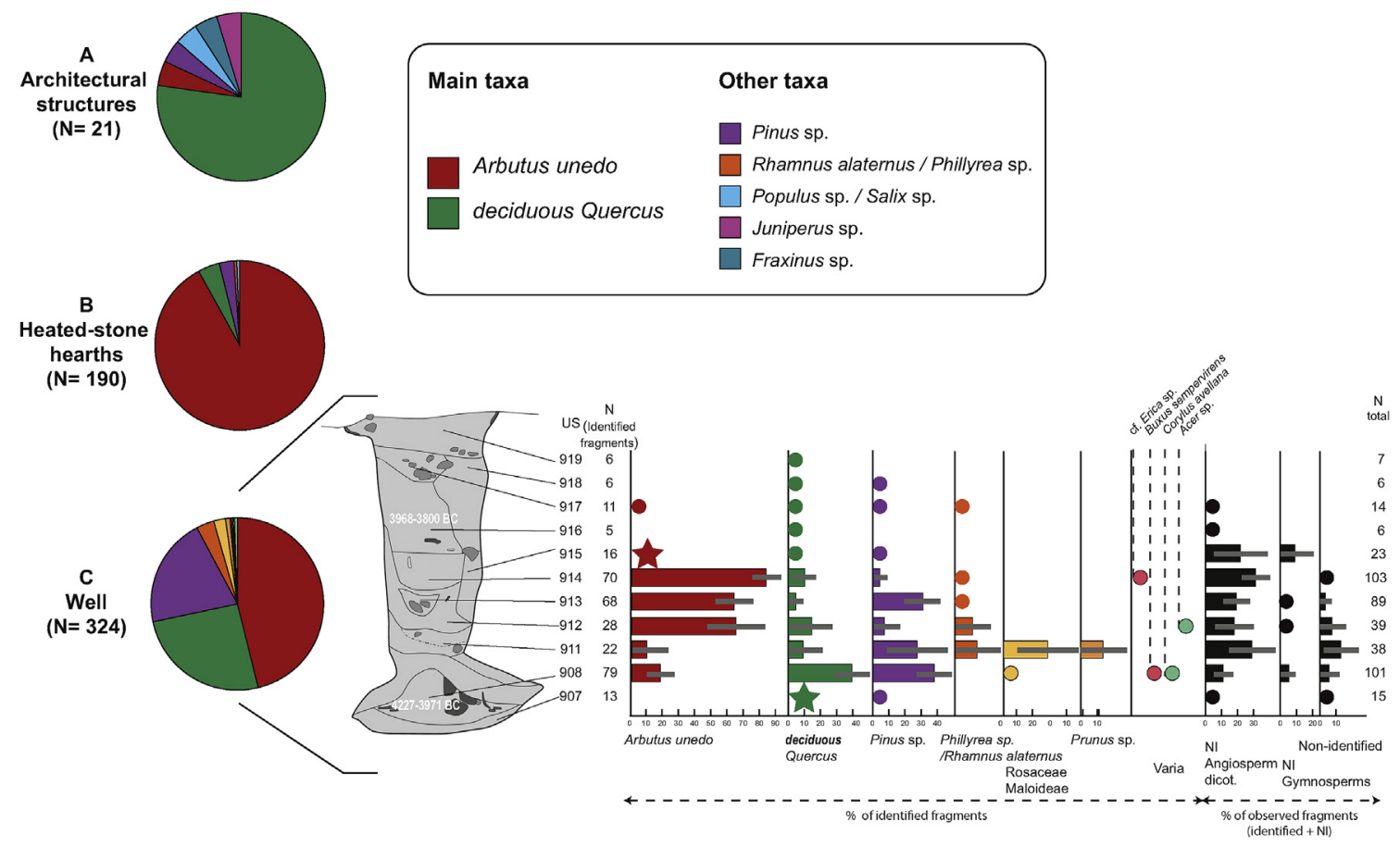

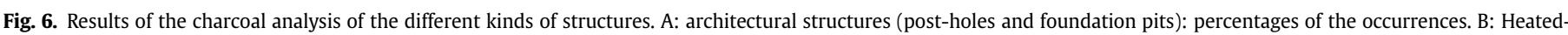

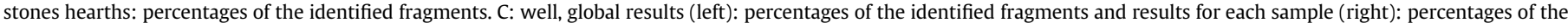

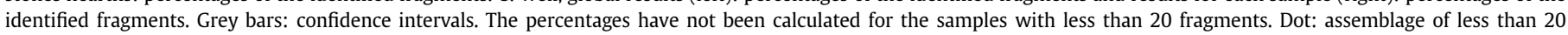
fragments or number of fragments of the taxon $=1$; star: dominant taxon in assemblages of less than 20 fragments. 
of gnarled and vitrified Arbutus fragments. Nevertheless, the preservation of knots or vitrified charcoal comparatively to normal and not vitrified wood has not been tested so far, and it would not detract from the fact that Arbutus is nearly the only taxon identified in fuel remains.

Even if they did not all functioned during the same period and they were not abandoned synchronously, seven out of the eight hearths studied provided nearly only Arbutus charcoal (in the eighth charcoal was not abundant: only three fragments of pine were identified). If we consider that the harvest of wood was made randomly in the available ligneous biomass, the low biodiversity of charcoal assemblages must be linked to the exploitation of pure Arbutus stands, except if the operators of the fire randomly chose Arbutus logs to feed the fire just before the hearth was abandoned. As the results are so similar, in seven cases out of eight, mere coincidence seems their least likely explanation. We should therefore investigate the possibility that Arbutus has been preponderant in the surrounding ligneous vegetation during the Middle Neolithic, which is not currently the case.

Arbutus grows in Mediterranean scrublands. It prefers acid substrata but it can be found on more or less decarbonated soils in limestone areas (Aubert, 1977). It can be favored by disturbances such as fire, grazing or frequent cutting. Arbutus-dominated formations are reported on crystalline substrata, in ravines from the Maures massif (Eastern Provence) (Rameau et al., 2008) and considered as a potential climax in humid or sub-humid bioclimates in Corsica (Panaiotis, 1995). They are also mentioned on the pelites (Permian sandstones) in the surroundings of the lake Salagou in Languedoc (at Carlencas, L. Liottier, pers. com.) and even in the calcareous hinterlands of Montpellier at La Boissière (L. Chabal, pers. com.). Nevertheless, this species very rarely forms dense and pure stands. It is usually found in the form of scattered trees, in formations dominated by evergreen oak garrigue, Mediterranean pine pinède or Erica arborea maquis, more rarely in deciduous oak forests (Aubert, 1977). With the exception of siliceous or extensively decarbonated soils, it is mostly a secondary element of retrogressive open woody formations (mid-successional according to Mesléard and Lepart, 1991) which tolerates dry and shallow soils. Currently, the geological and pedological context of Cazan seems unfavorable to the settlement of Arbutus-dominated maquis, even if isolated trees are scattered on the Chaîne des Costes. Several pollen diagrams are available for the lower Rhône/Durance area (Fig. 1). The closest from Cazan were sampled at 25/30 km from the site on both bank of the Durance river and date back to the end of the 1970's (Triat-Laval, 1978). More recently, two well-dated pollen cores were studied in the Marais des Baux (Andrieu-Ponel et al., 2000), around $30 \mathrm{~km}$ west from the site, in an area quite similar, edaphically and botanically speaking. In Triat-Laval's study, the Ericaceae - not identified to the genus level - show a subcontinuous curve (but never exceed $5 \%$ of the identified pollen grains) since the end of the Boreal at Beauchamp-Panières and Mollèges and appear sporadically at Les Autures but are not recorded at L'Isle-sur-la-Sorgue. The evergreen oak curve is more or less synchronous, showing somewhat higher values (but always below 10\%), and increases more at the top of the diagrams (in particular at Mollèges). The more recent analyses from the Marais des Baux allowed most of the time identifying the Ericaceae, which proved to be mainly represented by Erica arborea whose curve seems again to accompany - although remaining more modest that of evergreen oak. Arbutus is listed as a "rare taxon" in one of the profiles ( 2 pollen grains identified in a single sample whose pollen sum is 378), and totally absent from the other one, where nonidentified Ericacea gather 36 pollen grains from 5 samples (representing together a pollen sum of more than 1800). The representation of Arbutus in pollen spectra is not always representative of its abundance in the vegetation ("poor pollen producer": Reille, 1992), and seems to have mainly a local significance (Díaz Fernández, 1994). Even if the spatial and chronological accuracy of these data are not representative of the locally exploited vegetation during the decades when the site of Cazan was occupied, they do not indicate the existence of extended Arbutus-dominated associations in the region during the Middle Neolithic.

Very dense stands of Arbutus are not documented in the past and are currently unknown in the surrounding nor - to our knowledge - in any climatically or edaphically comparable location. Therefore, the charcoal spectra from the hearths do not seem to have been formed through a random sampling of the vegetation. The species usually found together with Arbutus in present-day associations (Erica arborea, evergreen Quercus, Phillyrea sp., Cistus sp., Pinus) are absent or very weakly represented (one fragment of Phillyrea sp./Rhamnus alaternus and five of Mediterranean Pinus out of 190 identified fragments). Based on these observations, the hypothesis that Arbutus was specifically selected for fuel in the heated-stone hearths seems the most plausible explanation. Assuming this hypothesis, the reproducibility of the results from one combustion structure to another would suggest that the use of Arbutus could have been a standard practice reiterated during the successive occupations. Equally, it does not preclude a wider or denser Neolithic distribution of Arbutus in the area, on more evolved and decarbonated soils than currently encountered, but in the present state of our knowledge no data supports that hypothesis.

\subsection{The well}

As a long-lasting, secondary deposit, not directly linked to a single charcoal producing activity, the well was expected to propose a reliable record of the ligneous diversity of the site. Instead, the diversity remains low, with only 10 taxa, of which 5 are present only in one sample each (Prunus sp., cf. Erica, Corylus avellana, Buxus sempervirens and Acer sp.) and the list of taxa does not really provide new information compared to that of the other structures. Arbutus and oak are well represented (46 and $25.6 \%$ of the identified fragments), even if the bad state of charcoal probably leads again to an under-estimation of Arbutus. Only the representation of pine $(20.4 \%)$ is better than it was in the other structures. Despite the infilling of the well, which is clearly formed by 3 successive phases, no variation is indicated by the charcoal spectra. As the well is located in the immediate vicinity of the hearths, and considering the abundance of Arbutus, it is possible that charcoal remains have been discarded in this structure after cleaning of the fireplaces.

\section{Discussion}

\subsection{Low overall taxonomic diversity: bias of the archaeological record or wood selection?}

The global biodiversity perceived through charcoal analysis at Cazan is low. Nevertheless, the recorded plants potentially refer to several different kinds of vegetation: seral stages of the deciduous oak forest, evergreen or mixed mesomediterranean formations (garrigue/maquis), pine formations and riparian forests (or at least an alluvial facies of the deciduous oak forest). However, the charcoal spectrum seems incomplete and fails to reflect the whole spectrum of the ligneous biodiversity of these associations. With three taxa (oak, Arbutus and pine) that supply more than $90 \%$ of the fragments, the charcoal assemblage is obviously only a partial record of the available vegetation.

Taphonomic processes may have affected the formation or the preservation of the charcoal record and be responsible for the 
incompleteness of the spectra. Given the lack of a preserved occupation soil, charcoal was recovered from the sediment-traps the negative structures are, which casts doubts as to its reliability as an indicator of the whole diversity of the wood used on the site throughout the entire period of occupation (Chabal, 1997). Nevertheless, the charcoal accumulation in the well can be considered as continuous and long lasting ( 3 phases of deposition can be distinguished and the ${ }^{14} \mathrm{C}$ dates cover the whole span of the Late Chassey culture occupation) and is not directly linked to a single specific charcoal-producing activity (secondary deposit). Yet, the range of biodiversity displayed in the deposits, despite being wider than the heated-stone structures or of the postholes, remains limited (10 taxa, among which 3 represent $92 \%$ of the fragments) and brings only few taxa different from those identified in these specialized structures (Acer sp., Buxus sempervirens, Corylus avellana, cf. Erica sp., Prunus sp., Maloideae), while the two most abundant remain the same (Arbutus unedo and deciduous oak). Moreover, the architectural features on the one hand and the heated-stone hearths on the other hand gave very similar results from one sample to another, in the same kind of structure, and very different results between one type of structure to another: the hearths are dominated by Arbutus (91.6\% of the fragments), while the postholes and foundation pits mainly provided deciduous oak (76.2\% of the occurrences).

All of these observations support the hypothesis that harvests of timber and fuel are dissociate activities carried out either in two distinct targeted zones consisting of different vegetations, or possibly in the same area but involving two different taxa. Based on our data, it seems difficult to determine the level where the selection is done. The decision may intervene when choosing either (i) where to gather the woody resources or (ii) what to gather among the woody resources. In the first case, it corresponds to an opportunistic random harvest, among the available wood in the plots of land visited for specific activities - timber collection, fuel procurement - or during any other activity associated to one of them (it is well documented that fuel gathering often goes together with other daily tasks: Dufraisse et al., 2007; Salavert and Dufraisse, 2014; Henry et al., 2009). In the second case, it corresponds to a targeted search for a particular species, leading to the exploitation of the plot of land where that species grows.

We support that the significant lack of diversity in charcoal assemblages produced through specialized activities and the reproducibility of the results from one architectural feature to another and from a combustion structure to another is better in favor of a selection of the species. Oak seems to be preferred for making posts and avoided as a fuel for collective heated-stone hearths; Arbutus seems to be preferred for that purpose. The facts that these choices appear repeatedly - in several buildings for the use of oak, in several hearths for the use of Arbutus - and that these two species remain the most abundant throughout the stratigraphy of the well seem to confirm that the targeted harvests of these taxa are not unique events but persisting practices.

\subsection{Contribution of charcoal analysis to the documentation of the buildings}

The density of the features at Cazan presents, for the first time, a unique opportunity to reconstruct the form in plan of these « houses », built by the chassey culture. Based on these observations it was also possible to define a chronology for multiple phases of occupation and abandon. Various data concerning the arrangement of the postholes (they never recut older features and they form a standardized plan), the composition of their fills (evidence of post pullout prior to backfilling), the archaeological material they contain (possible foundation deposits, deposed or dumped material) and radiocarbon dates show that the excavated area was occupied and abandoned at least three times, in probably less than three centuries (Moreau et al., 2015). Charcoal analysis from the postholes indicates that the posts were mostly made of deciduous oak. The preserved fragments show signs of duraminization. If the posts were made by large diameter logs, they could have originally included heartwood and sapwood. In that case, the complete decay of sapwood before carbonization would result in the preservation of heartwood only. Nevertheless, exclusive use of heartwood -especially of oak-is the only efficient way to ensure a durable wooden structure (sapwood is considered as unusable by present day carpenters) and seems more likely. Nor is the presence of ash (Fraxinus) and willow/poplar (Populus/Salix) surprising, as they can grow tall and provide relatively straight trunks or branches with sufficient diameters. Concerning the two finds of juniper and Arbutus in foundation pits, despite the smaller size of the charcoal fragments (compared to the average size of the fragments from postholes), their use as posts cannot be dismissed. If they are currently found in the form of small trees and coppices, both can reach several meters high and a diameter of several dozens of centimeters that can make them appropriate for making posts. However, in these two cases, intrusive charcoal is also possible.

The fact that oak fragments show signs evidences of duraminization as well as pre-combustion rotting features documents the chronology of the successive occupations. After the abandonment of the houses, the posts had time to partly decay, but were still present when the time for reconstruction came. Their remnants were then extracted and/or burnt, the holes were then backfilled with sediment and/or wastes and stone blocks; new holes were then dug for new posts. The durability of oak heartwood is of 15-25 years (Centre technique du bois et de l'ameublement, 1992; Association des ingénieurs de l'école supérieure du bois, 2013) which is an indication of the time-span between the building of the houses and the carbonization of the posts and thus between two successive occupations.

\subsection{Arbutus as a fuel: a technical choice or the result of a larger landscape management?}

The persistent use of Arbutus as fuel over the supposed 3 occupation phases is evidenced by its abundance in every hearth studied (except one structure which only provided 3 fragments of pine) and by the diachronic charcoal record of the well. The reproducibility of the results suggests that it would be too simplistic to ascribe the composition of the charcoal assemblages only to their being poorly representative of anything else other than the last combustion-event because they were recovered from combustion structures (Chabal, 1997). The charcoal analysis indicates that certain vegetal associations including Arbutus existed in the territory exploited by the Neolithic inhabitants of Cazan, but also, according to us, for a preference of that taxa for a specific use, as shown by a very poor quantitative and qualitative representation of the trees and shrubs which are usually associated with it (evergreen oak and tree heather are absent from the hearths; deciduous oak, Phillyrea/Rhamnus and pine represent together less than $8 \%$ of the identified fragments). Such a selection may be intended to satisfy cultural requirements that will remain unknown to us, but it could also fit technical or economical requirements.

Arbutus is still currently considered as a "good fuel" (KuhnholtzLordat, 1939, p.46; Lieutaghi, 2004) and has been used since the Iron Age to make charcoal (Fabre and Gervet, 1992; AcovitsiótiHameau, 2001; Durand et al., 2010) of high calorific value, used in particular in forges in Western Spain until recent times (González et al., 2013). Unfortunately, it is not possible, in the present state 
of charcoal analysis techniques, to distinguish charcoal produced by the use of wood as fuel from charcoal remaining from a second burning of already charred wood (Britton et al., 2007). To our knowledge, there is no report yet of Neolithic structures which could be linked to the deliberate production of wood charcoal. As a consequence, we tend to interpret charcoal spectra pre-dating iron metallurgy as the result of the combustion of wood, but the possibility of the use of charcoal - either produced for this purpose or recovered from previous fires - should be kept in mind. Whatever the form used (fresh wood or charred wood), it is possible that Arbutus was considered by the people living at Cazan as the best for the heated-stone hearths, either because of its intrinsic properties or, if used fresh, just because of the size of its branches. Nevertheless, the size alone is not a sufficient criteria as many other species could offer similar dimensions. Heated-stone structures are a particular type of hearth, typical of the Chassey culture for the Neolithic period. Despite improvements in recording and sampling of these features, due to a special attention given to them during field excavations and post-excavation analyses and recent experimental work (Muller-Pelletier, 2006), their functioning is not completely understood yet. Nevertheless, it seems widely accepted that "the objective is not the flame but the heat" (Muller-Pelletier and Pelletier, 2010): fire is used to start the heat-transfer process which is then mostly realized by the hot stones. Charcoal analyses of such Neolithic structures are not frequent to our knowledge (Cabanis, 2006; Marchand et al., 2009; Morin in Thirault, 2011, Figueiral, 2016), partly because they do not always provide charcoal. Comparisons are made difficult due to the reduced number of studies and the wide biogeographical range they concern. The taxonomic diversity and the identified taxa vary a lot from one site to another. In Languedoc (South of France), in the middle Neolithic hearths from the sites of Peras and Cadoules, most of the charcoal identifications points to Erica sp. (Figueiral, 2016), which belongs to the same family as Arbutus (Ericaceae), shows some ecological and biological similarities with it and has also been widely used to produce charcoal during middle ages (Durand et al., 2010). All the studies point to a high rate of vitrification (Cabanis, 2006; Marchand et al., 2009; Morin in Thirault, 2011, Figueiral, 2016), sometimes interpreted as an evidence of green wood (Cabanis, 2006) or of anaerobic combustion (Marchand et al., 2009). The process by which the cell walls melt is not well understood and none of the parameter which have been tested experimentally (which are: species, temperature, kinetics, green/seasoned wood, moisture) proved to be sufficient (Théry-Parisot, 2001; McMarland et al., 2009; McParland et al., 2010). The only variable not sufficiently tested to our knowledge is combustion in a reducing atmosphere. Successful experimental reproductions of the phenomenon have only been reported in charcoal kilns (Fabre, 1996) and in fire mining using green wood (Py and Ancel, 2006). The lack of oxygen during combustion should be investigated, not only as a mean to explain vitrification but to also improve our understanding of the function of the heated-stone hearths. We reported numerous radial cracks in Arbutus charcoal, whose accurate quantification could give information on the phenological state of the wood (Théry-Parisot and Henry, 2012). Unfortunately, Arbutus charcoal often displays a poorly readable transversal section (knots, vitrification), making such analysis difficult to achieve.

However, even if the kinetics of combustion of Arbutus is suitable for use in the heated-stone structures, other reasons may also explain its use for fuel. Plant resources management depends on the behavior of plants. Arbutus has a rapid juvenile growth, and, when brunt or cut, it produces clump shoots, ensuring a quick regeneration of the resource after harvesting. As a component of the scrublands, it is found in disturbed areas, like pasturelands or previously burnt zones (Kuhnholtz-Lordat, 1939). We thus can imagine that the specific exploitation of Arbutus is part of a land management system in which the scrublands are used both as grazing areas and as fuel supplies. As a feed-back, Arbutus could be to some extent favored by such management and gain importance in the vegetation compared to less competitive species. Meanwhile, oak timbers are preserved for use in construction. As shown by the charcoal from the well, pine is also exploited, although its use is not directly recorded. This could be because its primary deposits were not preserved (due to the truncation of the archaeological horizon) or alternatively because it was processed outside the excavation area.

\section{Conclusion}

Despite the absence of a preserved occupation soil and the restriction of charcoal remains availability to negative structures only, the site of Vernègues, Cazan - Le Clos du Moulin provides precious information not only about the vegetation cover around the site during the Middle Neolithic - which still needs to be better understood - but also about the socio-economic system. The study of assemblages from different types of structures linked to different activities grants opportunity to reconstruct some aspects of a specialized use of woody species. Posts are made of oak. Once rotten, they are cleared by fire, but oak is not used as a fuel in community hearths: Arbutus seems specifically chosen for that purpose, despite multiple sources of evidence which suggest it was not the most abundant species in the surrounding vegetation. The Neolithic population of Cazan practiced other charcoal-producing activities, including at least one that used the pine wood and that excavations did not revealed. If the size required for the posts and the need for a durable material can restrict the scope of the species suitable for timber, the choice of fuel seems to be less constrained by technical limitations. Nevertheless, a clear selection persists throughout the occupation of the site; it may be intended to satisfy cultural requirements that will remain unknown to us, but it could also fit technical or economical requirements.

The harvesting and the management of ligneous resources seem to be governed by socio-economic rules that must be linked to a broad exploitation of the landscape diversity, in particular for agropastoral purposes. The connection between agro-pastoral practices and firewood gathering according to a principle of landmanagement optimization has already been proposed for the Neolithic (Delhon et al., 2009; Salavert and Dufraisse, 2014; Battentier et al., 2016b). The charcoal analysis of Cazan allowed us to reconstruct the organization of wood-consuming activities in details, which echoes the strict organization of the habitat that has been demonstrated the first time at Cazan, but also the complex socio-economical organization of Chassey culture communities described by several authors at the regional scale (Beeching et al., 2000; Bréhard et al., 2010; Beeching, 2011; Beeching and Léa, 2015). The specific exploitation of Arbutus could then be a part of a land management system in which the scrublands are used both as grazing areas and as fuel supplies.

\section{Acknowledgment}

The authors wish to thank Xavier Margarit (Service Régional de l'Archéologie Provence-Alpes-Côted'Azur) and Didier Binder (CEPAM, CNRS) for connecting them and for their advices during the field excavation. Our attention was drawn to the Arbutus formations in Languedoc by Lucie Chabal (ISEM, CNRS) and Léonor Liottier (LabEx ArcHiMedE \& CEPAM, CNRS).The micromorphological analysis was done by Cristiano Nicosia (Université libre de Bruxelles). We benefited from constructive remarks from two reviewers which helped us to improve the manuscript. 


\section{References}

Acovitsióti-Hameau, A., 2001. Aller au charbon... Les sites de charbonnage et leur impact sur les paysages forestiers de la colline varoise. Forêt méditerranéenne XXII (4), 329-344.

Andrieu-Ponel, V., Ponel, P., Jull, A., de Beaulieu, J.-L., Bruneton, H., Leveau, P., 2000. Towards the reconstruction of the Holocene vegetation history of Lower Provence: two new profiles from Marais des Baux. Veg. Hist. Archaeobotany 9, $71-84$.

Asouti, E., Austin, P., 2005. Reconstructing woodland vegetation and its exploitation by past societies, based on the analysis and interpretation of archaeological wood charcoal macro-remains. Environ. Archaeol. 10, 1-18.

Association des ingénieurs de l'école supérieure du bois, 2013. Manuel de l'ingénierie bois. Eyrolles, Paris, p. 682.

Aubert, G., 1977. Essai d'interprétation écologique de la répartition des Ericacées en Provence (région du sud-est de la France). Ecol. Mediterr. 3, 113-123.

Bakour, R., 2003. Influence de l'espèce et de la provenance des chênes français sur la structure anatomique et les propriétés physiques des merrains. Thèse. ENGREFNancy.

Battentier, J., Cauliez, J., Théry-Parisot, I., Delhon, C., 2016a. Vegetal Landscape and its Management in Provence at the End of the Neolithic (2880-2580 Cal. BC) New Data provided by the Charcoal Analysis of Limon-Raspail (Vaucluse, Southeastern France). submitted for publication. Submitted to Quaternary International.

Battentier, J., Lepère, C., Théry-Parisot, I., Carré, A. and Delhon, C., 2016b. La grotte de Pertus II (Méailles, Alpes-de-Haute-Provence): exploitation du couvert forestier au Chasséen récent (3850-3650 cal. BC). In: Cauliez, J., Sénépart, I., Jallot, L., de Labriffe, P.-A, Gilabert, C., Gutherz, X. (Dirs.), De la tombe au territoire Actualité de la Recherche, Actes des 11eme rencontres Méridionales de Préhistoire Récente, 223-232.

Battentier, J., Thiébault, S., Binder, D., Théry-Parisot, I., Carré, A., Delhon, C., 2015. L'abri Pendimoun (Castellar, Alpes-Maritimes) : nouvelles données sur l'évolution du couvert forestier et l'exploitation du milieu au Néolithique (5800-2000 ans cal. BCE). Quaternaire 26 (4), 279-292.

Beeching, A., 2011. Habitats pérennes ou précaires au Néolithique. Tech. Cult. 56 30-47.

Beeching, A., Berger, J.-F., Brochier, J.-L., Ferber, F., Helmer, D., Sidi Maamar, H., 2000. Chasséens : agriculteurs ou éleveurs, sédentaires ou nomades? Quels types de milieux, d'économies et de sociétés. In: Leduc, M., Valdeyron, N., Vaquer, J. (Eds.), Sociétés et espaces. Actes des III ${ }^{\text {emes }}$ Rencontres méridionales de Préhistoire récente, Toulouse, 1998, Archives d'écologie préhistorique, pp. 59-79.

Beeching, A., Léa, V., 2015. Interroger les mobilités des sociétés du Néolithique : l'exemple du Chasséen méridional. In: Naudinot, N., Meignen, L., Binder, D., Querré, G. (Eds.), Les systèmes de mobilité de la Préhistoire au Moyen-âge. Actes des XXXVe rencontres internationales d'archéologie et d'histoire d'Antibes, Editions APDCA, Antibes, 2015, pp. 273-289.

Bréhard, S., Beeching, A., Vigne, J.-D., 2010. Shepherds, cowherds and site function on middle Neolithic sites of the Rhône valley: an archaeozoological approach to the organization of territories and societies. J. Anthropol. Archaeol. 29, 179-188.

Britton, C., Chabal, L., Pagès, G., Schneider, L., 2007. Approche interdisciplinaire d'un bois méditerranéen entre la fin de l'antiquité et la fin du Moyen Âge, Saugras et Aniana, Valène et Montpellier. Médièvales 53, 65-80.

Brochier, J.E., Claustre, F., Heinz, C., 1998. Environmental impact of Neolithic and Bronze Age farming in the eastern Pyrenees forelands, based on multidisciplinary investigations at La Caune de Belesta (Bélesta Cave), near Perpignan, France. Veg. Hist. Archaeobotany 7, 1-9.

Cabanis, M., 2006. Les macrorestes végétaux. In: Pelletier, D., Muller-Pelletier, C. (Eds.), (dirs.) : Cournon d'Auvergne, « zac des Acilloux », (Puy-de-Dôme Auvergne), Le site 1 : une concentration de structures de combustion à pierres chauffées du Néolithique moyen 1. Rapport d’opération, pp. 106-112. Inrap, Bron.

Centre Technique du Bois et de l'Ameublement, 1992. Guide pour le choix des bois en menuiserie, p. 164

Chabal, L., 1997. Forêts et sociétés en Languedoc (Néolithique final, Antiquité tardive). L’anthracologie, méthode et paléoécologie. Documents d'archéologie française 63. éditions de la Maison des Sciences de l'Homme, Paris, p. 192.

Delhon, C., 2016. Les assemblages de charbons en dépôts "concentrés" : une nouvelle méthode de calcul pour améliorer leur représentativité du bois mis au feu. Archéosciences 40.

Delhon, C., Thiébault, S., Berger, J.-F., 2009. Environment and landscape management during the middle Neolithic in Southern France: evidences of agro-sylvopastoral systems in the middle Rhone valley. Quat. Int. 200, 50-65.

Díaz Fernández, P., 1994. Relations between modern pollen rain and mediterranean vegetation in Sierra Madrona (Spain). Rev. Palaeobot. Palynol. 82, 113-125.

Dufraisse, A., Pétrequin, A.-M., Pétrequin, P., 2007. La gestion du bois de feu : un indicateur des contextes socio-écologiques. Approche ethnoarchéologique dans les Hautes Terres de Papua (Nouvelle-Guinée indonésienne). In: Besse, M. (Ed.), Sociétés Néolithiques. Des Faits Archéologiques Aux Fonctionnements Socioéconomiques, vol. 108. Cahiers d'archéologie romande, pp. 115-126.

Durand, A., Duval, S., Vaschalde, C., 2010. Le charbonnage des Ericacées méditerranéennes : approches croisées archéologiques, anthracologiques et historiques. In: Delhon, C., Théry-Parisot, I., Thiébault, S. (Eds.), Des hommes et des plantes. Exploitation du milieu et gestion des ressources végétales de la
Préhistoire à nos jours. Editions ADPCA, Antibes, pp. 323-333.

Fabre, L., 1996. Le charbonnage historique de la chênaie à Ouercus ilex L. (Languedoc, France) : conséquences écologiques. Thèse Doctorat. Université Montpellier II.

Fabre, L., Gervet, X., 1992. Première approche du charbonnage et de l'histoire de la forêt méditerranéenne : l'exemple du canton d'Aniane (Hérault). Bull. de société Bot. de Fr. 139, 617-625. Actualités botaniques (2/3/4).

Figueiral, I., 2016. Peras (1 et 2) (Mauguio) et Cadoules (Mudaison) : l'apport de l'archéobotanique. In: Escallon, G., Fritz, R. (Eds.), Languedoc-Roussilon, Hérault, Ligne Grande Vitesse - contournement de Nîmes-Montpellier. Secteurs 7/8 Mauguio-Mudaison - Peras et Cadoules. Vol. II. Les Cadoules, la Courconne et le Peras. Habitat du Néolithique, sépulture du Néolithique moyen et vaste occupation diachronique du Préchasséen au Chasséen classique. RFO, Inrap Méditerranée, Nîmes, pp. 497-504.

Ghazil, S., 2010. Etude de la migration des fluides dans le bois. Thése Universite Nancy 1.

González, J.A., García-Barriuso, M., Ramírez-Rodríguez, R., Bernardos, S., Amich, F, 2013. Plants used as fuel in the Arribes del Duero Natural Park (SalamancaZamora, Spain). Bot. Complut. 37, 181-190.

Heinz, C., 1990. Dynamique des végétations holocènes en méditerranée nordoccidentale d'après l'anthracoanalyse de sites préhistoriques. méthodologie paléoécologie. Paléobiologie Cont. XVI (2), 212.

Heinz, C., Thiébault, S., 1998. Characterization and palaeoecological significance of archaeological charcoal assemblages during Late and Post-Glacial phases in southern France. Quat. Res. 50 (1), 56-68.

Henry, A., Théry-Parisot, I., Voronkova, E., 2009. La gestion du bois de feu en forêt boréale : archéo-anthracologie et ethnographie (région de l'Amour, Sibérie). In: Théry-Parisot, I., Costamagno, S., Henry, A. (Eds.), Fuel Management during the Palaeolithic and Mesolithic Periods. New Tools, New Interpretations. British Archaeological Reports International Series 1914, pp. 17-37.

Kuhnholtz-Lordat, G., 1939. La Terre Incendiée: Essaid'agronomie Comparée. Editions de la Maison Carrée, Nîmes, p. 361.

Lieutaghi, P., 2004. Le livre des arbres, arbustes et arbrisseaux. Actes Sud. Nat. 1328.

Marchand, G., Mens, E., Carrión Marco, Y., Berthaud, G., Kerdivel, G., George, E. Quesnel, L., Vissac, C., 2009. Creuserpuis brûler: foyers et carriers néolithiques de Mazières-en-Mauges "le Chemin Creux" (Maine-et-Loire). Bull. de Société préhistorique française 106 (4), 735-759.

McParland, L., Collinson, M., Scott, A., Campbell, G., Veal, R., 2010. Is vitrification in charcoal a result of high temperature burning of wood? J. Archaeol. Sci. 37, 2679-2687.

McMarland, L., Collinson, M., Scott, A., Campbell, G., 2009. The use of reflectance values for the interpretation of natural and anthropogenic charcoal assemblages. Archeaological Anthropol. Sci. 1, 249-261.

Mesléard, F., Lepart, J., 1991. Germination and seedling dynamics of Arbutus unedo and Erica arborea on Corsica. J. Veg. Sci. 2, 155-164.

Molinier, R., Archiloque, A., Borel, L., Devaux, J.P., Lavagne, A., Moutte, P., 1976. Carte de végétation de la France, feuille de Marseille.

Moreau, C., Ancel, M.-J., Astruc, L., Bosc-Zanardo, B., Cattin, F., Delhon, C., Gilles, A. Léa, V., Linton, J., 2014. Vernègues, Cazan (Bouches-du-Rhône) : découverte d'un habitat structuré du Chasséen récent. Bull. de Société Préhistorique Française 111 (2), 341-344.

Moreau, C., Ancel, M.-J., Astruc, L., Bosc-Zanardo, B., Brochier, J.-E., Cattin, F. Collombet, J., Delhon, C., Foucras, S., Foulché, A.-L., Gerez, J., Gilles, A., GuichardKobal, L., Howarth, L., Magnin, F., Léa, V., Linton, J., Nicosia, C., Pacotte, L., Sénépart, I., Thirault, E., Caballero, N., Elodie-Guerrero, Y., Fuentes, J., Perez, P., Repellin, T., Varlet-Zago, L., Turgis, G., 2015. Vernègues, Cazan, Le Clos du Moulin (Parcelle B2-523). Un habitat structuré du Néolithique moyen entre 4100 et 3800 avant notre ère. Rapport final d'opération d'archéologie préventive. Archeodunum, SRA Provence-Alpes-Côte-d'Azur, p. 1145.

Muller-Pelletier, C., 2006. Les structures de combustion chasséennes de l'ensemble C2c de la doline de Roucadour : micro-histoires, fonctionnements et analyse spatiale. In: Gascó, J., Leuge, F., Gruat, P. (Eds.), Hommes et passé des Causes, Hommage à Georges Costantini. Editions des Archives d'Ecologie Préhistorique, Toulouse, pp. 223-252.

Muller-Pelletier, C., Pelletier, D., 2010. Les structures à pierres chauffées du Néolithique moyen du site 1 des Acilloux (Cournon-d'Auvergne, Puy-de-Dôme) In: Beeching, A., Thirault, E., Vital, J. (Eds.), Economie et société à la fin de la Préhistoire. Actualité de la recherche. Documents d'Archéologie en RhôneAlpes et en Auvergne, ALPARA, pp. 305-315.

Ozenda, P., Pautou, G., Portecorp, J., 1970. Carte de végétation de la France, feuille de Digne.

Panaiotis, C., 1995. Diversité structurale des formations forestières à chêne vert (Quercus ilex L.) et des maquis de la forêt domaniale du Fango (Réserve de la Biosphère). Travaux Sci. du Parc Naturel Régional de Corse des réserves Naturelles 48, 1-68.

Py, V., Ancel, B., 2006. Archaeological experiments in fire setting: protocol, fuel and anthracological approach. In: Dufraisse, A. (Ed.), Charcoal Analysis: New Analytical Tools and Methods for Archaeology. Bar International Series 1483 pp. 71-82.

Rameau, J.-C., Mansion, D., Dumé, G., Gauberville, C., 2008. Flore Forestière Française. Guide Écologique Illustré. Tome 3 : Région Méditerranéenne. Institut pour le développement forestier.

Reille, M., 1992. New pollen-analytical researches in Corsica: the problem of Quercus ilex L. and Erica arborea L., the origin of Pinus halepensis Miller forests. New Phytol. 122, 359-378.

Salavert, A., Dufraisse, A., 2014. Understanding the impact of socio-economic 
activities on archaeological charcoal assemblages in temperate areas: a comparative analysis of firewood management in two Neolithic societies in Western Europe (Belgium, France). J. Anthropol. Archaeol. 35, 153-163.

Schweingruber, F.H., 1990. Anatomy of European Woods. Bern/Stuttgart: P. Haupt p. 800 .

Smart, T.L., Hoffman, E.S., 1988. Environmental interpretation of archaeological charcoal. Chicago, London. In: Hastorf, C.A., Popper, V.S. (Eds.), Current Paleoethnobotany, pp. 165-205.

Théry-Parisot, I., 2001. Economie des combustibles au Paléolithique. Expérimentation, anthracologie, Taphonomie. D.D.A. 20. CNRS-Editions, Paris, p. 195.

Théry-Parisot, I., Henry, A., 2012. Seasoned or green? Radial cracks analysis as a method for identifying the use of green wood as fuel in archaeological charcoal. J. Archaeol. Sci. 39, 381-388.

Théry-Parisot, I., Texier, P.J., 2006. L'utilisation du bois mort dans le site moustérien de la Combette (Vaucluse). Apport d'une approche morphométrique des charbons de bois à la définition des fonctions de site, au Paléolithique. Bull. de Société Préhistorique Française 103 (3), 453-463.

Thiébault, S., 1997. Early-Holocene vegetation and the human impact in central Provence (Var, France) charcoal analysis of Baume de Fontbrégoua. Holocene 7 (3), 341-347.

Thiébault, S., 2001. Anthracoanalyse des établissements néolithiques de la région liguro-provençale. Bull. de Société Préhistorique Française 98 (3), 399-409.

Thirault, E., 2011. Les occupations chasséennes de Cazan-l'Héritière, à Vernègues. Rapport final d'opération, Paléotime, SRA PACA.

Triat-Laval, H., 1978. Contribution pollenanalityque à l'Histoire Tardi- et Postglaciaire de la végétation de la basse vallée du Rhône. Thèse de l'Université d'Aix-Marseille III, p. 343.

Vernet, J.-L., Ogereau, P., Figueiral, I., Machado Yanes, C., Uzquiano, P., 2001. Guide d'identification des charbons de bois préhistoriques et récents. Sud-Ouest de l'Europe : France, Péninsule ibérique et îles Canaries. CNRS Editions, p. 395. 